\title{
Flame-Made Calcium Phosphate Nanoparticles with High Drug Loading for Delivery of Biologics
}

\author{
Vasiliki Tsikourkitoudi ${ }^{1}{ }^{\mathbb{D}}$, Jens Karlsson ${ }^{1}{ }^{(}$, Padryk Merk1 ${ }^{1}$, Edmund Loh ${ }^{1,2}{ }^{\circledR}$, \\ Birgitta Henriques-Normark ${ }^{1,2,3}$ and Georgios A. Sotiriou ${ }^{1, *(D)}$ \\ 1 Department of Microbiology, Tumor and Cell Biology, Karolinska Institutet, SE-1 7177 Stockholm, Sweden; \\ vasiliki.tsikourkitoudi@ki.se (V.T.); jens.karlsson@ki.se (J.K.); padryk.merkl@ki.se (P.M.); \\ edmund.loh@ki.se (E.L.); birgitta.henriques@ki.se (B.H.-N.) \\ 2 Lee Kong Chian School of Medicine (LKC) and Singapore Centre on Environmental Life Sciences \\ Engineering (SCELSE), Nanyang Technological University, Singapore 639798, Singapore \\ 3 Department of Clinical Microbiology, Karolinska University Hospital, SE-171 76 Stockholm, Sweden \\ * Correspondence: georgios.sotiriou@ki.se
}

Academic Editors: Paola Luciani and Davide Brambilla

Received: 16 February 2020; Accepted: 7 April 2020; Published: 10 April 2020

\begin{abstract}
Nanoparticles exhibit potential as drug carriers in biomedicine due to their high surface-to-volume ratio that allows for facile drug loading. Nanosized drug delivery systems have been proposed for the delivery of biologics facilitating their transport across epithelial layers and maintaining their stability against proteolytic degradation. Here, we capitalize on a nanomanufacturing process famous for its scalability and reproducibility, flame spray pyrolysis, and produce calcium phosphate (CaP) nanoparticles with tailored properties. The as-prepared nanoparticles are loaded with bovine serum albumin (model protein) and bradykinin (model peptide) by physisorption and the physicochemical parameters influencing their loading capacity are investigated. Furthermore, we implement the developed protocol by formulating CaP nanoparticles loaded with the LL-37 antimicrobial peptide, which is a biological drug currently involved in clinical trials. High loading values along with high reproducibility are achieved. Moreover, it is shown that CaP nanoparticles protect LL-37 from proteolysis in vitro. We also demonstrate that LL-37 retains its antimicrobial activity against Escherichia coli and Streptococcus pneumoniae when loaded on nanoparticles in vitro. Therefore, we highlight the potential of nanocarriers for optimization of the therapeutic profile of existing and emerging biological drugs.
\end{abstract}

Keywords: nanocarriers; drug delivery; biologics; calcium phosphate; flame spray pyrolysis; LL-37; stability; antimicrobial properties

\section{Introduction}

Biological drugs, also called biologics, are therapeutics that contain one or more active substances made by or derived from a biological source [1]. Biologics include proteins, antibodies, peptides, nucleotides and are an attractive class of therapeutic moieties for long-term medical illnesses/conditions with no other treatment available. Approximately $31 \%$ of all drugs approved by the US Food and Drug Administration (FDA) during the last 5 years were biologics [2]. Biologics exhibit high potency coupled with target specificity, however, there are some important challenges for their broad and effective employment: (i) their transport across various epithelial layers, such as skin and mucus, is limited due to their large size, (ii) they typically suffer from poor bioavailability via the oral route and, thus, can only be administered systemically (e.g., by injection) [3], (iii) they are susceptible to enzymatic degradation in tissues and plasma and consequently their circulation half-life is shortened.

To address these challenges, nanosized drug delivery systems have been proposed as a promising strategy for the delivery of biologics [4]. Nanoparticles can be used as drug carriers due to their 
high surface-to-volume ratio (large surface area/small size) that allows for their interaction with other similarly-sized biological entities. Most common nanocarriers in the literature are based on organic materials (e.g., liposomes, dendrimers, lipid nanoparticles) [5]. However, the mechanism of degradation of these organic nanomaterials in biological systems is not fully understood raising concerns regarding the biocompatibility of their degradation products [6].

Recently, the development of novel inorganic nanocarriers has gained significant attention and is considered among the fastest growing areas of drug delivery [7,8]. Phosphate-based nanocarriers have shown great potential due to their solubility in aqueous or slightly acidic conditions, their biodegradability and biocompatibility. They consist of divalent cations (usually $\mathrm{Ca}^{2+}[9], \mathrm{Mg}^{2+}$ [10], $\mathrm{Mn}^{2+}[10,11], \mathrm{Zn}^{2+}$ [12]) that form ionic complexes with macromolecules, that in turn can be easily transferred across cell membranes via ion channel mediated endocytosis [13]. Among them, calcium phosphate (CaP) nanoparticles are an important family of biomaterials in drug delivery because of their excellent biocompatibility, low toxicity, non-immunogenicity and osteoconductivity. In fact, the high biocompatibility of CaP nanoparticles renders it advantageous compared to polymeric, lipid-based, or other metal-based nanocarriers that may cause adverse effects and are not always biodegradable, and thus pose a risk of accumulation in the body [14]. The high biocompatibility of $\mathrm{CaP}$ nanoparticles is further supported by the fact that $\mathrm{CaP}$ is approved by the US FDA and is clinically available as bone graft formulation (Gem21S ${ }^{\circledR}$, Osteohealth). In this formulation, $\mathrm{CaP}$ acts both as a carrier of a biological drug (platelet-derived growth factor) and as a bone tissue regeneration matrix. This has prompted studies with $\mathrm{CaP}$ as a potential carrier for several biologics such as proteins [15], peptides [16-18] and nucleotides [9,19,20] against various diseases.

Despite the current scientific interest of nanoparticle-based therapeutics, there are still barriers for their clinical translation with the most important ones summarized below [21]:

(1) Complex synthesis methods of nanocarriers, that require multiple individual preparation steps, cannot be easily scaled up and reproduced leading to batch-to-batch inconsistencies.

(2) Poor loading efficiency of biological drugs in comparison to clinically relevant therapeutic doses. Many methods do not permit facile tuning of nanocarrier properties, such as specific surface area (SSA) and size, that directly affect drug loading. Typical loading values for liposomes are in the range of $1 \%-10 \%$, while for polymeric nanocarriers loading values do not surpass $20 \%$ [22,23]. Loading efficiency is a crucial factor determining the excipient amount in nanopharmaceutical products (i.e., nanoparticles in this case). In case of low loading, a larger amount of nanoparticles is needed in order to deliver a clinically relevant dose of the drug. However, an increase of the excipient amount might cause undesirable side effects and increase the manufacturing cost [5].

(3) Stability of the biological drug due to possible loss of its biological functionality during the loading process.

Technological developments for overcoming existing barriers are important to enable the future success of nanoformulations for drug delivery.

Here, we aim to address these challenges and engineer inorganic drug delivery nanocarriers by flame spray pyrolysis (FSP). We exploit the versatility of this scalable and reproducible nanomanufacturing process for the synthesis of $\mathrm{CaP}$ nanocarriers with tailored properties. FSP can produce multi-component nanoparticles with high control over their specific surface area (SSA)/size, composition and crystallinity in a single step [24,25]. A distinct target here is to maximize the biological drug loading on these nanocarriers. There are still large variabilities in the drug loading capacity of $\mathrm{CaP}$ nanocarriers described in the literature [26], highlighting the need for an improved protocol for the loading of biological drugs on the surface of nanocarriers. We develop here such an experimental protocol for loading biological drugs (proteins and peptides) on flame-made CaP nanoparticles by physisorption, an increasingly popular route for nanoparticle biofunctionalization [27]. We study the loading on CaP nanoparticles of two different SSA/sizes of two biomacromolecules, bovine serum albumin (BSA) and bradykinin as model protein and peptide, respectively. We therefore address challenges regarding insufficient stability, low drug loading capacity, expensive manufacturing and poor yield and unclear biocompatibility [28]. 
In order to further implement the developed protocol in biological drugs currently in use, we utilized the LL-37 antimicrobial peptide, currently being explored in several clinical trials for its antimicrobial, wound healing and immunomodulatory properties (see ClinicalTrials.gov Identifier: NCT02225366 \& NCT04098562) [29]. LL-37 has a net positive charge at physiological conditions, is amphiphilic and can eliminate the pathogenic microbes directly via electrostatic attraction towards negatively charged bacterial membranes [30]. Upon its immobilization on nanoparticle surfaces, LL-37 exhibits bactericidal activity against various bacteria [31-34]. Braun et al. [31] showed the effect of surface charge and SSA of mesoporous $\mathrm{SiO}_{2}$ nanocarriers on loading and release of LL-37 and they investigated their antimicrobial activity against Escherichia coli 25922. M. Vignoni et al. [35] investigated the antimicrobial behaviour of LL-37-loaded Ag nanoparticles in skin infections and its antibiofilm formation activity. In this case, they did not observe any bactericidal effect of LL-37 for Pseudomonas aeruginosa, Staphylococcus epidermidis and Staphylococcus aureus. The antibacterial effect was attributed to Ag nanoparticles, whereas LL-37 promoted proliferation of skin fibroblasts. Garcia-Orue et al. [36] demonstrated the antimicrobial activity of LL-37 encapsulated in nanostructured lipid carriers (NLC) against E. coli. These nanocarriers had $\sim 73 \%$ bacterial killing and significantly improved wound healing in vivo (mice) in comparison to free LL-37. Cherredy et al. [37] also investigated wound healing properties of LL-37 encapsulated in polymeric nanoparticles, and more precisely in poly (lactic-co-glycolic acid) (PLGA). Although PLGA-LL-37 formulation was more efficient in wound healing than free LL-37, it did not have any significant antimicrobial activity against E. coli as even at the highest LL-37 concentration tested $(5 \mu \mathrm{g} / \mathrm{mL})$, the survival of bacterial cells was $\sim 70 \%$. To the best of our knowledge, there are no studies so far demonstrating the use of CaP nanoparticles as LL-37 carriers. Exploring the current trend of developing novel antibiotics by antimicrobial peptides, we formulate LL-37-loaded CaP nanoparticles with high loading and high reproducibility. We further study the stability of the peptide upon its loading on CaP nanoparticles against proteinase $\mathrm{K}$ and investigate the antimicrobial activity against E. coli and Streptococcus pneumoniae.

\section{Results and Discussion}

\subsection{Particle Morphology}

Flame aerosol nanoparticle synthesis allows for a fine control over the product nanoparticle primary size by tuning the process conditions. More specifically, by controlling the precursor concentration and the flow rate of the dispersion gas $\left(\mathrm{O}_{2}\right.$ in this case) during FSP, CaP nanoparticles of different SSA are obtained, as measured by $\mathrm{N}_{2}$ adsorption. Table 1 shows the process conditions for the two samples made here and the resulting SSA. The average primary particle diameter, $d_{B E T}$, is calculated from the SSA assuming monodisperse solid spherical particles with density of $3.16 \mathrm{~g} / \mathrm{cm}^{3}$ [38]. Increasing precursor concentration during FSP yields larger primary particle sizes attributed to the longer particle residence time at high temperatures [39].

Table 1. Flame spray pyrolysis (FSP) processing conditions $\left(\mathrm{O}_{2}\right.$ dispersion gas flow rate, precursor flow rate and concentration) and calculated precursor concentration used for the synthesis of the calcium phosphate (CaP) nanoparticles, along with their specific surface area (SSA) measured by $\mathrm{N}_{2}$ adsorption and the corresponded primary particle diameter $\left(\mathrm{d}_{\mathrm{BET}}\right)$.

\begin{tabular}{ccccccc}
\hline Sample & $\begin{array}{c}\mathbf{O}_{2} \text { Dispersion } \\
\text { Gas Flow Rate } \\
(\mathbf{L} / \mathbf{m i n})\end{array}$ & $\begin{array}{c}\text { Precursor } \\
\text { Flow Rate } \\
(\mathbf{m L} / \mathbf{m i n})\end{array}$ & $\begin{array}{c}\text { Ca and } \mathbf{P} \\
\text { Concentration } \\
\mathbf{( M )}\end{array}$ & $\begin{array}{c}\text { Precursor Concentration } \\
\text { in Flame } \\
\left(\mathbf{m m o l}_{\mathbf{C a}+\mathbf{P}} / \mathbf{L}_{\mathbf{O} \text { disp }}\right)\end{array}$ & $\begin{array}{c}\text { SSA } \\
\left(\mathbf{m}^{2} / \mathbf{g}\right)\end{array}$ & $\begin{array}{c}\mathbf{d}_{\text {BET }} \\
(\mathbf{n m})\end{array}$ \\
\hline $\mathrm{CaP}_{\mathrm{L}}$ & 3 & 8 & 0.2 & 0.533 & 73 & 26 \\
$\mathrm{CaP}_{\mathrm{S}}$ & 8 & 3 & 0.1 & 0.0375 & 246 & 8 \\
\hline
\end{tabular}

The crystallinity of the as-prepared nanoparticles is evaluated by X-ray powder diffraction (XRD) and shown in Figure 1a, in which the characteristic hydroxyapatite (ICSD: 151414) and CaO (ICSD: 26959) crystal phases are also present. Broad reflections are shown for the $\mathrm{CaP}_{\mathrm{S}}$ sample, indicating 
the amorphous nature of the particles while sharp peaks are exhibited for the $\mathrm{CaP}_{\mathrm{L}}$ sample. Further minor sharp peaks corresponding to $\mathrm{CaO}$ exist in both samples ( $<4 \mathrm{wt} \%$ as determined by Rietveld analysis). Therefore, by controlling the precursor concentration within the flame, the crystallinity of the product nanoparticles is finely tuned from completely amorphous to highly crystalline, in agreement with the literature $[40,41]$. Representative transmission electron microscopy (TEM) images of both $\mathrm{CaP}_{\mathrm{L}}$ and $\mathrm{CaP}_{\mathrm{S}}$ nanoparticles are shown in Figure $1 \mathrm{~b}$ and $\mathrm{c}$, respectively. The characteristic fractal-like structure of flame-made nanoparticles consisting of agglomerates and/or aggregates with several primary particles within each agglomerate/aggregate is shown.
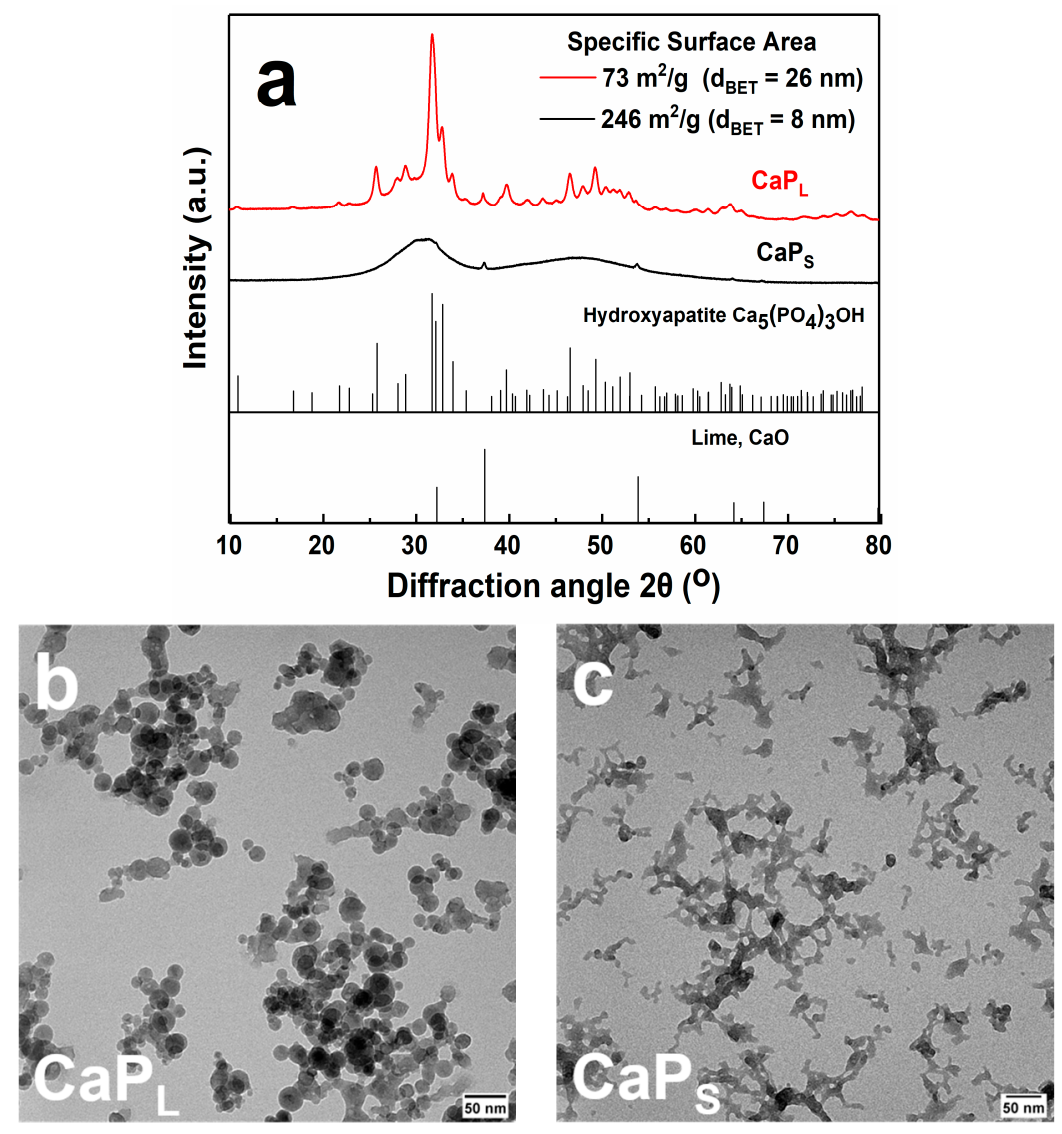

Figure 1. (a) X-ray diffraction (XRD) patterns of the CaP nanoparticles. The specific surface area (SSA), as determined by the nitrogen adsorption-desorption isotherms, along with the corresponding primary particle size, $\mathrm{d}_{\mathrm{BET}}$, are also shown. By varying FSP synthesis conditions either crystalline or amorphous particles are obtained. Main peaks are assigned to hydroxyapatite, $\mathrm{Ca}_{5}\left(\mathrm{PO}_{4}\right)_{3} \mathrm{OH}$, whereas $\mathrm{CaO}$ is also observed. Transmission electron microscopy (TEM) images of as-prepared $\mathrm{CaP}_{\mathrm{L}}(\mathbf{b})$ and $\mathrm{CaP}_{\mathrm{S}}(\mathbf{c})$ samples. $\mathrm{CaP}_{\mathrm{L}}$ particles are spherical with loosely agglomerated structure, while fused particles with sintered necks are clearly illustrated for $\mathrm{CaP}_{\mathrm{S}}($ Scale bar $50 \mathrm{~nm}$ ).

\subsection{Loading Macromolecules on CaP Nanoparticles: Effect of Incubation Time and Macromolecule Concentration}

The loading capacity of macromolecules on flame-made CaP nanoparticles by physisorption is studied with BSA and bradykinin as a model protein and peptide, respectively. BSA and bradykinin are incubated in phosphate-buffered saline (PBS) ( $\mathrm{pH} 7.4$ ) at room temperature along with both CaP samples for up to $24 \mathrm{~h}$ and constant particle and protein concentration (both at $500 \mu \mathrm{g} / \mathrm{mL}$ ). The effect of incubation time on the loading capacity is shown in Figure 2a,b, respectively. BSA and bradykinin rapidly physisorb on the nanoparticle surface during the first hour. The BSA loading capacity of both $\mathrm{CaP}_{\mathrm{S}}$ and $\mathrm{CaP}_{\mathrm{L}}$ nanoparticles increases over time. $\mathrm{CaP}_{\mathrm{S}}$ particles with higher SSA demonstrate slightly higher values for the same mass concentration than $\mathrm{CaP}_{\mathrm{L}}$ that are larger and have lower SSA (Table 1). 
The difference in loading capacity for the two samples might be attributed to the accessible surface area and thus the availability of binding sites between BSA and CaP nanoparticles; however, it is not proportional to the nominal SSA values of the two samples. This may be attributed to both the agglomeration/flocculation that occurs upon dispersion in liquids, but also because of the differences in crystallinity, as charged molecules might adsorb differently on surfaces depending on their crystal phase [42]. Agglomeration is energetically favorable and it is challenging to avoid in colloidal systems without any surface treatment (e.g., surface functionalization or coating) [43]. Bradykinin loading for both $\mathrm{CaP}_{\mathrm{s}}$ and $\mathrm{CaP}_{\mathrm{L}}$ reaches steady-state earlier than BSA probably due to its smaller size and the loading values do not differ significantly over the $24 \mathrm{~h}$ studied here. Nonetheless, the loading values for BSA and bradykinin reach $350 \mathrm{mg} / \mathrm{g}$ and $600 \mathrm{mg} / \mathrm{g}$ of CaP that further highlights the high loading capacity of the flame-made CaP nanoparticles. Because of the slightly higher loading capacity values exhibited from the $\mathrm{CaP}_{\mathrm{S}}$ sample, further results here focus on this size.
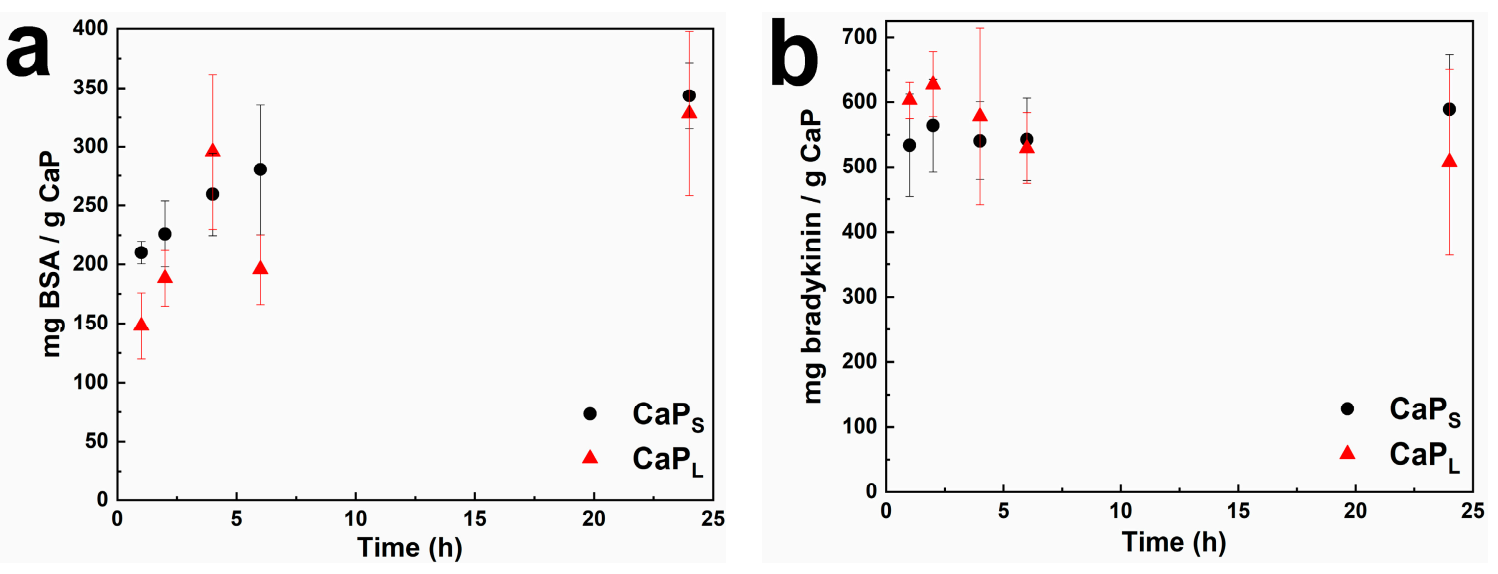

Figure 2. Effect of incubation time on the loading capacity of $\mathrm{CaP}_{\mathrm{S}}$ and $\mathrm{CaP}_{\mathrm{L}}$ nanoparticles for (a) bovine serum albumin (BSA); and (b) bradykinin ( $\mathrm{pH} 7.4$, particle concentration $500 \mu \mathrm{g} / \mathrm{mL}$, BSA/bradykinin concentration $500 \mu \mathrm{g} / \mathrm{mL}$ ). Both BSA and bradykinin rapidly adsorb on the nanoparticles' surface during the first hour.

Figure 3a shows the loading capacity of $\mathrm{CaP}_{\mathrm{S}}$ nanoparticles for BSA (blue circles) and bradykinin (red triangles) after incubation for $6 \mathrm{~h}$ as a function of the initial macromolecule concentration ( $\mathrm{pH} 7.4$ and particle concentration of $500 \mu \mathrm{g} / \mathrm{mL}$, please see Supplementary Materials, Figure $\mathrm{S} 1$ for $\mathrm{CaP}_{\mathrm{L}}$ ). By increasing BSA and bradykinin concentration in the range of 100 to $1000 \mu \mathrm{g} / \mathrm{mL}$, the adsorbed quantity on the nanoparticles monotonically increases. The BSA/bradykinin concentration has not reached saturation conditions up to $1000 \mu \mathrm{g} / \mathrm{mL}$ indicating that this concentration range is still in the linear part of the Langmuir isotherms [44]. Furthermore, the same procedure is employed to load LL-37 antimicrobial peptide on $\mathrm{CaP}_{\mathrm{S}}$ nanoparticles (black squares in Figure 3a, incubation for $4 \mathrm{~h}$ in PBS). Similar to BSA and bradykinin, the loaded amount increases for increasing LL-37 concentration. LL-37 exhibits more efficient physisorption than BSA and bradykinin at the same initial concentrations as shown in Figure $3 \mathrm{~b}$. This is probably attributed to the more cationic charge of LL-37 than BSA/bradykinin that enables LL-37 to readily physisorb on the CaP nanoparticle surface. The maximum LL-37 loading achieved here reaches $\sim 800 \mathrm{mg} / \mathrm{g}$ CaP, that outperforms all LL-37 loadings found in the literature (Table 2). This high loading is probably attributed to the fractal-like agglomerated/aggregated structure that is typical for flame-made nanomaterials (Figure 1b,c). We also show in Table 2 the minimum inhibitory concentration (MIC) values of LL-37 and of the nanoparticle dose (in $\mu \mathrm{g} / \mathrm{mL}$ ), as will be discussed later on. 

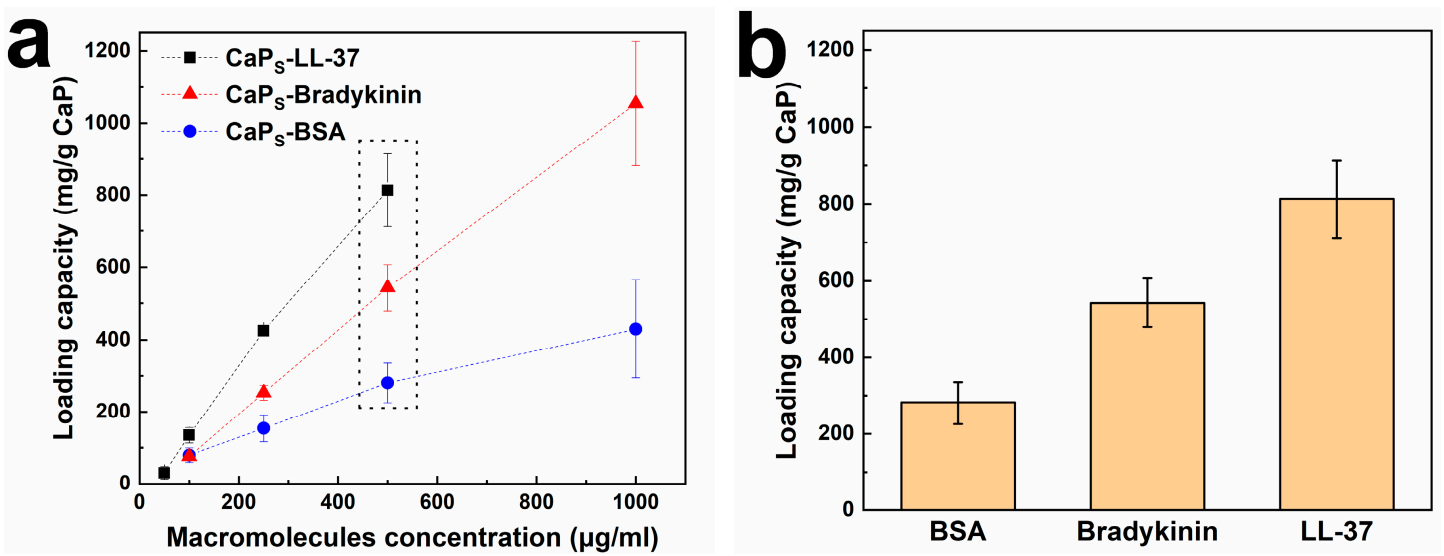

Figure 3. (a) Effect of concentration of BSA, bradykinin and LL-37 on the loading capacity of CaPs nanoparticles ( $\mathrm{pH} 7.4$, particle concentration $500 \mu \mathrm{g} / \mathrm{mL}$ ); (b) Loading capacity of CaPs nanoparticles for particle concentration $500 \mu \mathrm{g} / \mathrm{mL}$ and macromolecule concentration (i.e., BSA, bradykinin and LL-37) $500 \mu \mathrm{g} / \mathrm{mL}$. Data are reported as mean \pm standard deviation, for at least 3 independent triplicates.

Table 2. LL-37 loading values for various nanocarriers of different sizes reported in the literature. LL-37 loading values achieved in the present study for CaP nanocarriers outperform all LL-37 loading values found in the literature. Minimum Inhibitory Concentration (MIC) values of LL-37 and of the nanoparticle dose for the presented nanocarriers are also shown.

\begin{tabular}{|c|c|c|c|c|c|c|}
\hline Nanocarrier & $\begin{array}{l}\text { Hydrodynamic } \\
\text { Diameter (nm) }\end{array}$ & Pathogen & $\begin{array}{l}\text { LL-37 Loading } \\
\text { (mg/g particle) }\end{array}$ & $\begin{array}{l}\text { LL-37 MIC } \\
(\mu \mathrm{g} / \mathrm{mL})\end{array}$ & $\begin{array}{l}\text { NPs MIC } \\
(\mu \mathrm{g} / \mathrm{mL})\end{array}$ & Ref \\
\hline PLGA & 163 & $\begin{array}{c}\text { E. coli } \\
\text { (ATCC 25922) }\end{array}$ & $1.02 \pm 0.06$ & \multicolumn{2}{|c|}{$\begin{array}{l}\text { No significant antimicrobial } \\
\text { activity }\end{array}$} & [37] \\
\hline $\begin{array}{l}\text { Nanostructured } \\
\text { Lipid Carriers }\end{array}$ & 220.6 & $\begin{array}{c}\text { E. coli } \\
\text { (ATCC 25922) }\end{array}$ & $16.76 \pm 0.07$ & $\begin{array}{c}20 \\
\text { (72\% killing) }\end{array}$ & 1193 & [36] \\
\hline $\begin{array}{c}\text { Solid Lipid } \\
\text { nanoparticles }\end{array}$ & $\begin{array}{c}232.2 \\
\text { (loaded } \\
\text { particles) }\end{array}$ & $\begin{array}{c}\text { E. coli } \\
\text { (ATCC 25922) } \\
\text { S. aureus } \\
\text { (ATCC 25923) }\end{array}$ & $8.48-16.32$ & $\begin{array}{c}2-3 \\
(65-72 \% \text { killing }) \\
2-3 \\
(42-47 \% \text { killing })\end{array}$ & $184-236$ & [32] \\
\hline $\mathrm{Au}$ & $10.47 \pm 1.89$ & Methicillin-resistant S. aureus & 0.56 & 0.9 & 1536 & [45] \\
\hline $\begin{array}{l}\text { Mesoporous } \\
\mathrm{SiO}_{2}\end{array}$ & $\begin{array}{l}307.9^{*} \\
294.6^{*}\end{array}$ & $\begin{array}{c}\text { E. coli } \\
(\text { ATCC 25922) }\end{array}$ & $\begin{array}{c}24.1 * * \\
129.7^{* *}\end{array}$ & $\begin{array}{c}2.2 \\
44.9\end{array}$ & $\begin{array}{c}93 \\
346\end{array}$ & [31] \\
\hline $\begin{array}{l}\text { Calcium } \\
\text { Phosphate }\end{array}$ & $\begin{array}{c}230 \\
\left(\mathrm{~d}_{\mathrm{BET}}=8 \mathrm{~nm}\right)\end{array}$ & $\begin{array}{c}\text { S. pneumoniae } \\
\text { (T4, ATCC BAA-34) } \\
\text { E. coli } \\
\text { (HVM52) }\end{array}$ & $813.4 \pm 101.3$ & $\begin{array}{l}50 \\
200\end{array}$ & 246 & $\begin{array}{l}\text { This } \\
\text { work }\end{array}$ \\
\hline
\end{tabular}

* as determined by SEM. ${ }^{* *}$ Calculated assuming $\mathrm{SiO}_{2}$ particle density $2.2 \mathrm{~g} / \mathrm{cm}^{3}$ [46]. Detailed calculations are presented in Supplementary Materials.

In order to further study the presence of the macromolecules on the $\mathrm{CaP}_{\mathrm{S}}$ nanoparticle surface, Fourier-transform infrared spectroscopy (FTIR) analysis is performed on freeze-dried nanoparticles loaded with the biologics (Figure 4a). The successful physisorption of macromolecules onto the nanoparticle surface is confirmed in Figure $4 \mathrm{~b}$, that shows a magnification of the spectra, by the presence of new peaks around $1650-1680 \mathrm{~cm}^{-1}, 1540 \mathrm{~cm}^{-1}$ and $1360 \mathrm{~cm}^{-1}$, representing amide I, amide II and amide III bonds, respectively, in agreement with the literature. More precisely, amide I peaks are mainly associated with $\mathrm{C}=\mathrm{O}$ stretching vibrations, whereas amide II peaks are correlated to $\mathrm{C}-\mathrm{N}$ stretching and $\mathrm{N}-\mathrm{H}$ bending. Amide III bonds result from $\mathrm{CH}_{2}$ scissoring motion [44]. Moreover, as shown in Figure $4 \mathrm{a}$, when the spectra of loaded particles (red, blue and green lines) are compared to the spectrum of pure $\mathrm{CaP}_{\mathrm{S}}$ nanoparticles (black line), there is a decrease of the intensity of the $\mathrm{PO}_{4}{ }^{3-}$ bands and the disappearance of $\mathrm{CO}_{3}{ }^{2-}$ band. Even though the $\mathrm{CO}_{3}{ }^{2-}$ from the amorphous $\mathrm{CaP}_{\mathrm{S}}$ might dissolve in aqueous solutions resulting in the disappearance of that band, the reduction of the $\mathrm{PO}_{4}{ }^{3-}$ peak along with slight shifting of the peaks of pure BSA to higher wavenumbers for the loaded $\mathrm{CaP}_{\mathrm{S}}$ (green, red and blue lines in comparison to magenta line in Figure $4 \mathrm{~b}$ ) indicate that there is some interaction at these sites between the $\mathrm{CaP}$ and the macromolecules $[47,48]$. 

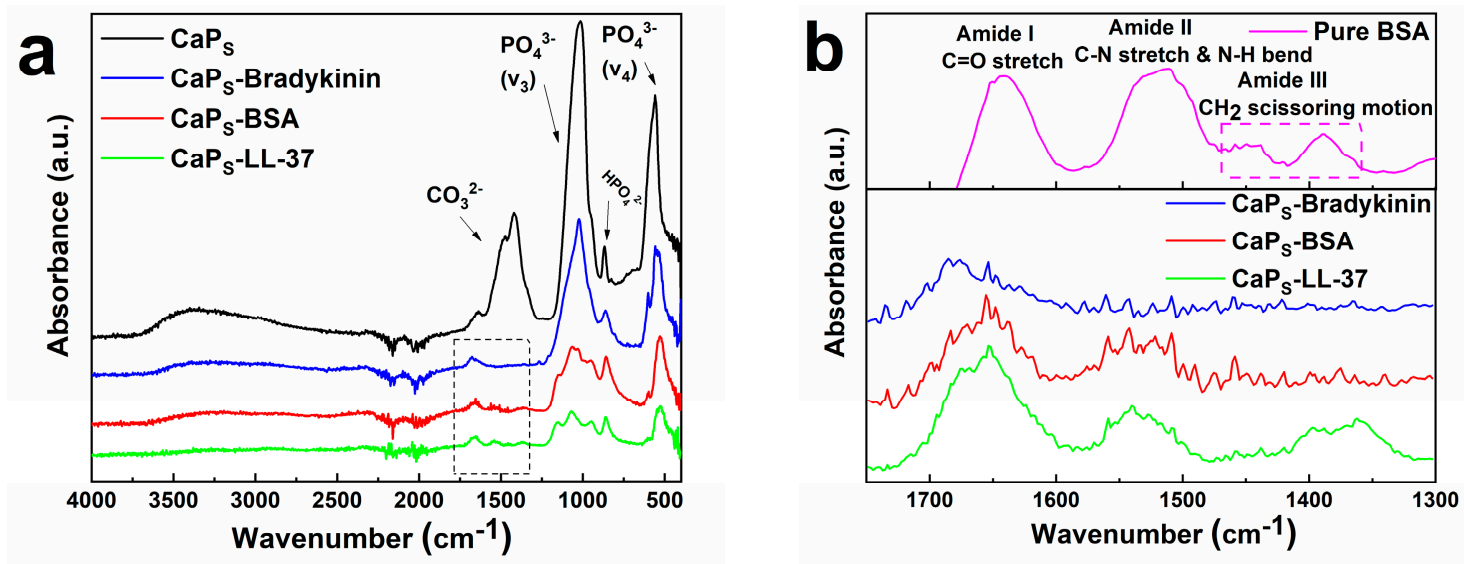

Figure 4. (a) Fourier-transform infrared spectroscopy (FTIR) spectra of $\mathrm{CaP}_{\mathrm{S}}$ and freeze-dried bradykinin, BSA and LL-37-loaded $\mathrm{CaP}_{\mathrm{S}}$ nanoparticles showing the characteristic absorption bands for phosphate chemical groups; (b) Magnified amide bond region indicating the presence of new peaks in the spectra of loaded samples, that represent amide I, amide II and amide III bonds.

The hydrodynamic size measured by dynamic light scattering (DLS) in PBS (particle concentration $100 \mu \mathrm{g} / \mathrm{mL}$ ) before and after macromolecule loading on the $\mathrm{CaP}_{\mathrm{S}}$ nanoparticles is shown in Figure $5 \mathrm{a}$ (number distribution, please see Figure S2 in Supplementary Materials the intensity distribution). The presence of protein/peptide seems to promote nanoparticle agglomeration due to increased agglomerate-agglomerate interactions. The developed nanocarriers here form agglomerates when suspended in solution in agreement with similar flame-made nanoparticles [49] and their sedimentation occurs over a few hours (Supplementary Material, Figure S5). Even though small hydrodynamic sizes are typically preferred for intravenous delivery, larger sizes might also be suitable for other administration routes, such as pulmonary (e.g., dry powder inhaler) or local administration (e.g., wound healing). Furthermore, the effect of $\mathrm{pH}$ on $\zeta$-potential values of the $\mathrm{CaP}_{\mathrm{S}}$ nanoparticles is shown in Figure $5 b$ (size distribution and $\zeta$-potential profile of $\mathrm{CaP}_{\mathrm{L}}$ are shown for comparison in Supplementary Materials, Figure S3, whereas the effect of $\mathrm{pH}$ on $\zeta$-potential values of pure BSA, pure bradykinin and pure LL-37 are shown in Supplementary Materials, Figure S4). The isoelectric point (IEP) of pure $\mathrm{CaP}_{\mathrm{S}}$ is determined to be $\sim 4.7$, whereas when loaded with BSA and bradykinin there is practically no change probably because of the similar IEP of pure BSA and bradykinin, respectively (Supporting Information, Figure S4). However, there is a significant increase of the IEP of CaPs particles to $\sim 7$, when they are loaded with LL-37, indicating the presence of LL-37 on the CaPS surface.
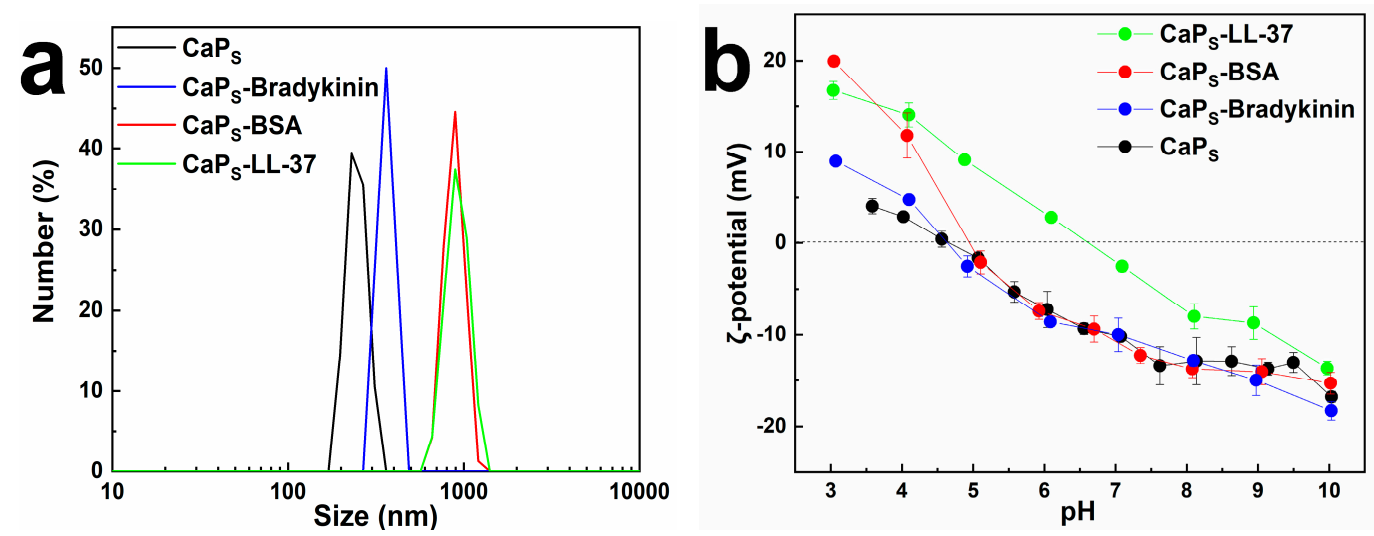

Figure 5. (a) Size distribution of $\mathrm{CaP}_{\mathrm{S}}$ nanoparticles (number \% data) before and after loading with BSA, bradykinin and LL-37 in phosphate-buffered saline (PBS) pH 7.4, as determined by dynamic light scattering (DLS) measurements (particle concentration $100 \mu \mathrm{g} / \mathrm{mL}$ ); (b) $\zeta$-potential profile of $\mathrm{CaP}_{\mathrm{S}}$ and loaded $\mathrm{CaP}_{\mathrm{S}}$ particles as determined by titration at different $\mathrm{pH}$ (particle concentration $100 \mu \mathrm{g} / \mathrm{mL}$ ). 


\subsection{Assessement of LL-37 Stability and Antimicrobial Assays}

\subsubsection{LL-37 Loading on CaP Nanoparticles Keeps LL-37 Intact from Degradation by Proteinase K}

Maintaining stability against enzymatic degradation and retaining biological functions of macromolecular drugs is crucial for biologics delivery systems. In order to assess the enzymatic degradation of LL-37 and the protective potential from the $\mathrm{CaP}_{\mathrm{S}}$ nanocarriers, a degradation assay utilizing Proteinase K was performed (Sodium Dodecyl Sulfate-Polyacrylamide Gel Electrophoresis, SDS-PAGE). Figure 6a shows a representative gel electrophoresis of the pure LL-37 and the LL-37 loaded on the $\mathrm{CaP}_{\mathrm{S}}$ nanoparticles after incubation with Proteinase $\mathrm{K}$ for up to $240 \mathrm{~min}$. A clear LL-37 band can be seen at a size of $4.5 \mathrm{kDa}$ which starts fading steadily after 20 min incubation in the case of pure LL-37 and new smears appear at lower molecular weight. The fading of the LL-37 band is attributed to its degradation over time because of proteolysis by proteinase K. LL-37 degradation by proteinase $\mathrm{K}$ has also been shown by Oren et al. (uncleaved peptide after $2 \mathrm{~h} \sim 5 \%$ ) [50]. However, when loaded on $\mathrm{CaP}_{\mathrm{S}}$, the LL-37 fully resists degradation up until $240 \mathrm{~min}$ incubation. Figure $6 \mathrm{~b}$ shows the quantification of these bands demonstrating that loading on $\mathrm{CaP}_{\mathrm{S}}$ offers protection of LL-37 against proteolytic degradation. This is in line with Braun et al. [31] who showed protection of LL-37 by $P$. aeruginosa elastase and leucocyte elastase when loaded on mesoporous $\mathrm{SiO}_{2}$ nanoparticles, and further highlights that such a macromolecule protection from enzymatic degradation occurs not only from mesoporous materials but also from fractal-like agglomerates/aggregates.
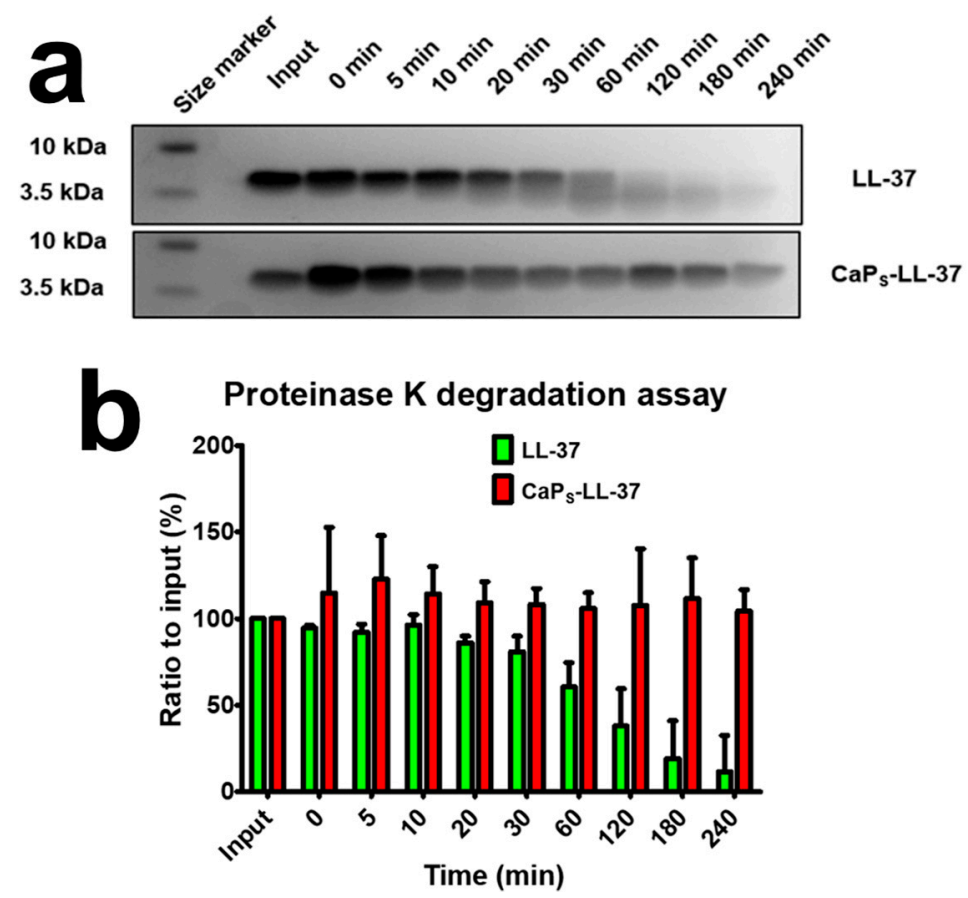

Figure 6. Proteinase $\mathrm{K}$ degradation assay of LL-37 in $20 \mathrm{mM}$ Tris- $\mathrm{HCl}, \mathrm{pH} 8.0$ with a total of 20 ng Proteinase K. (a) Representative Sodium Dodecyl Sulfate-Polyacrylamide Gel Electrophoresis (SDS-PAGE) gels before and after proteolytic degradation of pure LL-37 and LL-37-loaded on CaP nanoparticles. A clear LL-37 band can be seen at a size of $4.5 \mathrm{kDa}$ which starts degrading steadily after $20 \mathrm{~min}$ incubation, however, when loaded on $\mathrm{CaP}_{\mathrm{S}}$, the LL-37 resists degradation up until $240 \mathrm{~min}$ incubation. Input is the pure LL-37 or LL-37-loaded on $\mathrm{CaP}_{\mathrm{S}}$ nanoparticles $\left(\mathrm{CaP}_{\mathrm{S}}\right.$-LL-37) without any proteinase K added. Gel pictures shown are representative of at least three repetitions; (b) Quantification of bands for numerical assessment of degradation. Error bars are shown as standard deviation $(\mathrm{N}=3)$. 


\subsubsection{Antimicrobial Activity of LL-37-Loaded $\mathrm{CaP}_{\mathrm{S}}$}

To verify if the LL-37 retains its antimicrobial function after being physisorbed onto CaPS nanoparticles, its antimicrobial activity was studied against two bacterial pathogens, E. coli and S. pneumoniae. Figure 7 shows the background-subtracted (see Supplementary Materials for background signals, Figure S6) optical density at $\lambda=600 \mathrm{~nm}\left(\mathrm{OD}_{600}\right)$ as a function of time for $20 \mathrm{~h}$ of cultures containing the E. coli (a) and the S. pneumoniae serotype 4 strain TIGR4 (T4) (b) incubated either with the pure LL-37 or the LL-37-loaded nanoparticles for concentrations of LL-37 $=50-100 \mu \mathrm{g} / \mathrm{mL}$ for E. coli and $5-50 \mu \mathrm{g} / \mathrm{mL}$ for $S$. pneumoniae. The $\mathrm{OD}_{600}$ values directly correlate to the concentration/population of the bacterial cultures [51]. Figure 7a shows that pure LL-37 barely inhibits the E. coli growth up to $100 \mu \mathrm{g} / \mathrm{mL}$, but most importantly that the LL-37-loaded nanoparticles also exhibit antimicrobial activity with the ones of the highest LL-37 concentration exhibiting better performance than the pure peptide. This might be attributed to the protective effect of $\mathrm{CaP}_{\mathrm{S}}$ nanoparticles to LL-37 from secreted proteinases by the pathogens during the in vitro assay, leading to higher active concentration of LL-37 when it is loaded on the $\mathrm{CaP}_{\mathrm{S}}$ nanoparticles than when it is free. The antimicrobial effect is even more pronounced against S. pneumoniae (Figure $7 \mathrm{~b}$ ), in which both pure LL-37 peptide and the LL-37-loaded nanoparticles completely inhibit the bacterial growth at LL-37 concentration of $50 \mu \mathrm{g} / \mathrm{mL}$. At LL-37 concentration of $25 \mu \mathrm{g} / \mathrm{mL}, \mathrm{CaP}_{\mathrm{S}}$-LL-37 induce early lysis of the bacterial cell. At the lowest concentration $(5 \mu \mathrm{g} / \mathrm{mL})$, pure peptide seems to be more effective than peptide-loaded nanoparticles, as it completely inhibits bacterial growth, whereas CaPS-LL-37 inhibit bacterial growth up to $50 \%$ (as maximum $\mathrm{OD}_{600}$ attained, $\sim 0.2$, is approximately half of the maximum $\mathrm{OD}_{600}$ attained for the positive control, $\sim 0.4$ ). The growth curve of $\mathrm{T} 4$ (positive control, black line in Figure $7 \mathrm{~b}$ ) is typical for S. pneumoniae, as the $\mathrm{OD}_{600}$ decrease after reaching maximum values is attributed to autolysis of the pathogen [52].
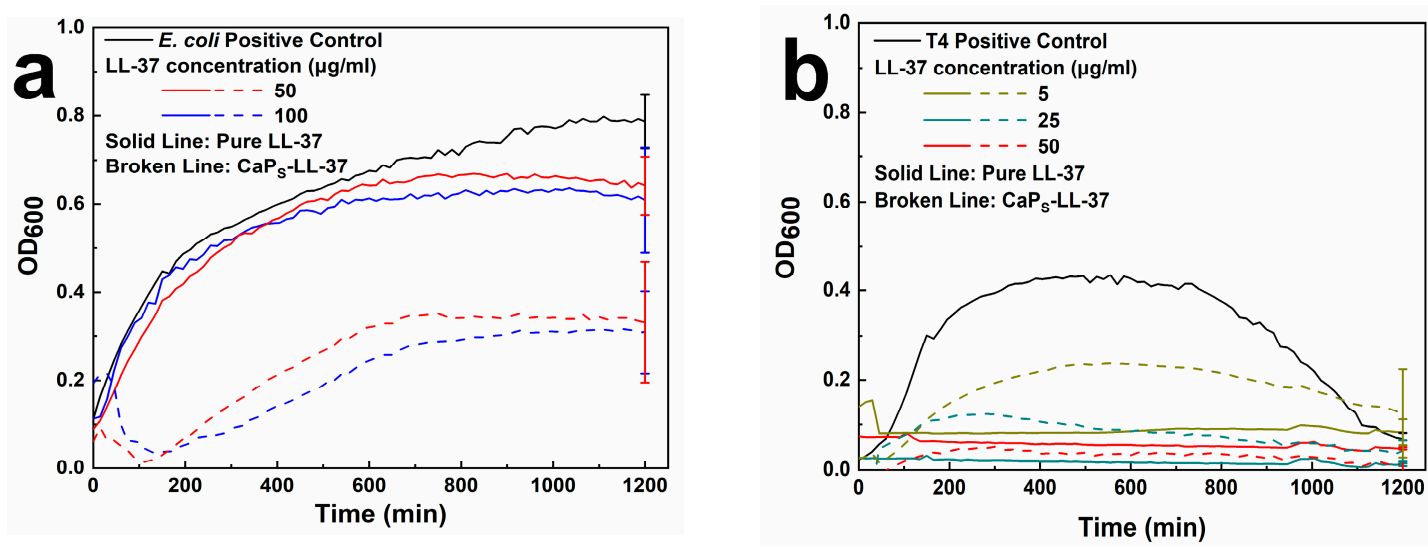

Figure 7. Growth curves ( $\mathrm{OD}_{600}$ vs. time) of (a) E. coli (HVM52); (b) S. pneumoniae (T4), after subtraction of background (Figure S6). Measurements had been performed at least in triplicate and mean values are presented with representative error bars.

In Figure 8, the $\mathrm{OD}_{600}$ values for all LL-37 concentrations tested are presented for E. coli (a) and S. pneumoniae (b). For E. coli (Figure 8a), the antimicrobial activity of LL-37-loaded CaPS nanoparticles outperforms the activity of pure peptide for all the concentrations tested. $\mathrm{OD}_{600}$ values for LL-37 concentrations of 200 and $400 \mu \mathrm{g} / \mathrm{mL}$ for $\mathrm{CaP}_{\mathrm{S}}$-LL-37 conjugates are shown as zero as after background subtraction they are negative. For S. pneumoniae (Figure 8b), the antimicrobial activity of $\mathrm{CaP}_{\mathrm{S}}$-peptide conjugates is similar to that of the pure peptide at concentrations higher than $5 \mu \mathrm{g} / \mathrm{mL}$. The presence of pure particles did not exhibit any growth inhibition and the observed antibacterial activity is attributed to the LL-37 peptide and not to the $\mathrm{CaP}_{\mathrm{S}}$ nanoparticles (see Supplementary Materials, Figure S7). The fact that LL-37 and LL-37-loaded $\mathrm{CaP}_{\mathrm{S}}$ are more effective towards S. pneumoniae than E. coli was expected as E. coli (and other Gram-negative bacteria, like P. aeruginosa) is more resistant towards LL-37 
than S. pneumoniae (Gram-positive) [53,54]. Most importantly, these results highlight that the loading of LL-37 onto the flame-made nanoparticles fully retains the peptide functionality and highlights the potential of these nanoparticles as biological drug nanocarriers. Furthermore, from these graphs the MIC values of the LL-37-loaded $\mathrm{CaP}_{\mathrm{S}}$ may also be calculated as shown in Table 2. Upon comparing the MIC values from the present study and those from literature in Table 2, it is highlighted that low LL-37 MIC values do not necessarily mean a low nanocarrier dose, and further showing that the high LL-37 loading values achieved here facilitate the clinical translation of flame-made CaP nanoparticles as biological drug nanocarriers.
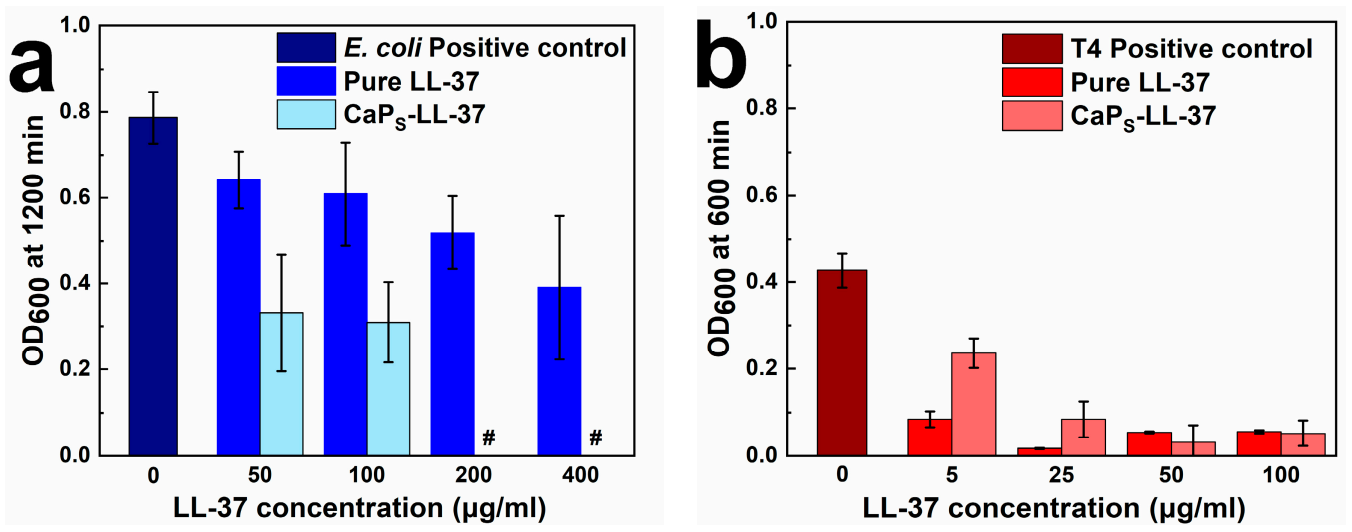

Figure 8. $\mathrm{OD}_{600}$ values at (a) $1200 \mathrm{~min}$ for E. coli (HVM52); (b) $600 \mathrm{~min}$ for S. pneumoniae (T4) for all LL-37 concentrations tested. Measurements had been performed at least in triplicate. Mean values after subtraction of background (Figure S6) are presented. In (a), \# denotes negative $\mathrm{OD}_{600}$ due to background subtraction (plotted as zero in the graph for simplicity).

The LL-37 release from the $\mathrm{CaP}_{\mathrm{S}}-\mathrm{LL}-37$ nanoconjugates at $25^{\circ} \mathrm{C}$ and $37^{\circ} \mathrm{C}$, at $\mathrm{pH} 7.4$ after $2 \mathrm{~h}, 6 \mathrm{~h}$ and $24 \mathrm{~h}$ is further studied in which we observe negligible release, $<2 \%$ for both temperatures (Table S2 in the Supplementary Materials) indicating that the antibacterial activity is mainly attributed to direct bacterial contact with the nanoparticles. In order to further investigate the antibacterial mechanism of the $\mathrm{CaP}_{\mathrm{S}}$-LL-37 nanoparticles, we acquire images by fluorescence microscopy of bacterial cultures tracking both the bacteria (stained green by SYTO9 Green Fluorescent Nucleic Acid Stain that labels both live and dead bacteria) and the nanocarriers (stained red by their intrinsic luminescence due to the $\mathrm{Eu}^{3+}$ ion doping, please see Materials and Methods, Section 3.1) after incubation for $2 \mathrm{~h}$ at $37^{\circ} \mathrm{C}$ with the LL-37-loaded CaPS nanoparticles (LL-37 concentration $400 \mu \mathrm{g} / \mathrm{mL}$ ). The images in Figure 9 show E. coli (green) attached onto the $\mathrm{CaP}_{\mathrm{S}}-\mathrm{LL}-37$ agglomerates (red). We could not detect any $S$. pneumoniae T4 bacteria at these conditions indicating that all bacteria have been lysed already (images not shown). This further indicates that the antibacterial mechanism is mainly through direct bacterial contact with the nanoparticles.
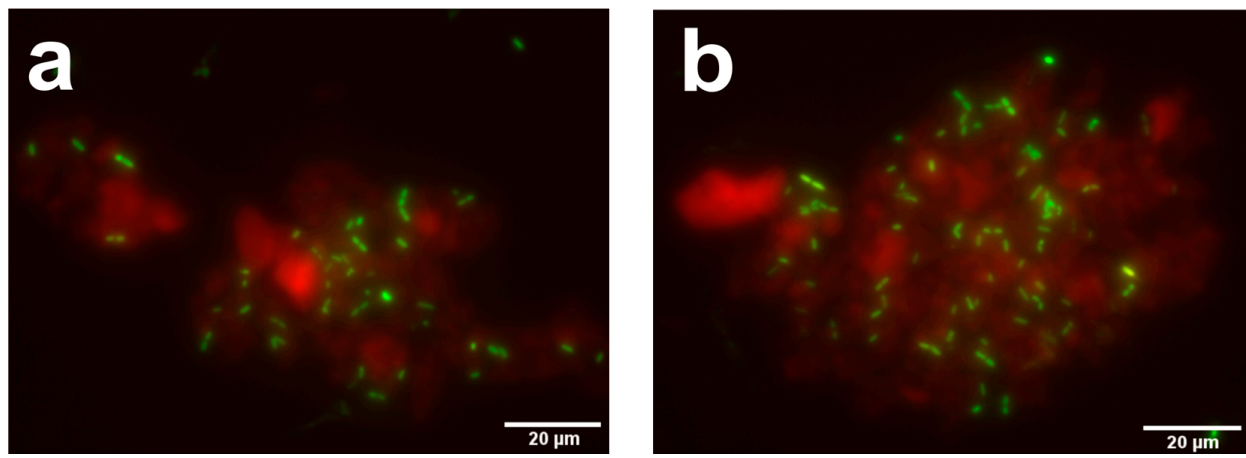

Figure 9. Representative z-stack projection images acquired by fluorescence microscopy showing $E$. coli (in green) (LL-37 concentration $400 \mu \mathrm{g} / \mathrm{mL}$ ) attached on LL-37-loaded CaPS agglomerates (in red) after $2 \mathrm{~h}$ incubation time at $37^{\circ} \mathrm{C}$. 


\section{Materials and Methods}

\subsection{Particle Synthesis and Characterization}

CaP nanoparticles doped with 5 at\% europium (vs. Ca) were produced by FSP. The Eu-doping enabled the detection of the $\mathrm{CaP}$ nanoparticles by monitoring their luminescence. Initially, calcium and europium precursors, i.e., calcium acetate hydrate ( $\geq 99 \%$, Sigma-Aldrich, Stockholm, Sweden) and europium nitrate hexahydrate (99.9\%, Alfa Aesar, Kandel, Germany), respectively, were added in the solvent mixture comprised by 2-ethylhexanoic acid (99\%, Sigma-Aldrich, Stockholm, Sweden) and propionic acid ( $\geq 99.5 \%$, Sigma-Aldrich, Stockholm, Sweden) in 1:1 ratio and stirred under reflux for $30 \mathrm{~min}$ at $70{ }^{\circ} \mathrm{C}$. Subsequently, tributyl phosphate ( $\geq 99 \%$, Sigma-Aldrich, Stockholm, Sweden) was added (phosphorus precursor), after clear solution was observed, in appropriate quantity in order to obtain $\mathrm{Ca} / \mathrm{P}$ molar ratio of 2.19. A high $\mathrm{Ca} / \mathrm{P}$ molar ratio is chosen in order to prevent dissolution of the particles, which highly depends on $\mathrm{Ca} / \mathrm{P}$ molar ratio (increased dissolution is observed with decrease of $\mathrm{Ca} / \mathrm{P}$ molar ratio). The total metal concentration of the precursor solution was $0.1 \mathrm{M}$ or $0.2 \mathrm{M}$. The precursor solution was delivered to the flame through a capillary tube (SGE Analytical Science, Milton Keynes, UK) using a syringe pump (New Era Pump Systems, Inc., Farmingdale, NY, USA). The solution was atomized in the FSP nozzle by oxygen gas ( $>99.5 \%$, Linde AGA Gas AB, Stockholm, Sweden) (EL-FLOW Select, Bronkhorst, Ruurlo, Netherlands) at constant pressure (1.8 bar). The synthesis of the particles was carried out at $X: Y$ 3:8 and 8:3 where $X$ is the ratio of the precursor feed flow rate $(\mathrm{mL} / \mathrm{min})$ and $\mathrm{Y}$ is the $\mathrm{O}_{2}$ dispersion gas flow rate $(\mathrm{L} / \mathrm{min})$. The spray flame was ignited by a premixed supporting flame of methane/oxygen (> 99.5\%, Linde AGA Gas AB, Stockholm, Sweden) at flow rates of $1.5 \mathrm{~L} / \mathrm{min}$ and $3.2 \mathrm{~L} / \mathrm{min}$, respectively. The particles were collected on a glass fiber filter (Albet LabScience, Dassel, Germany) with the aid of a Mink MM 1144 BV vacuum pump (Busch, Mölnlycke, Sweden).

Phase identification of the as-prepared powders was performed by X-Ray diffraction (XRD). XRD data were collected at ambient temperature with a MiniFlex X-ray diffractometer (Rigaku Europe, Neu-Isenburg, Germany) utilizing Cu K $\alpha 1$ radiation (1.5406 ̊) and operating at $40 \mathrm{kV}$ and $15 \mathrm{~mA}$. XRD patterns were recorded between 10 and $80^{\circ} 2 \theta$ at a step size of $0.01^{\circ}$. Rietveld refinement was performed using the Rigaku software. The specific surface area (SSA) was determined by the nitrogen adsorption-desorption isotherms (Brunauer-Emmett-Teller, BET method,) in liquid nitrogen at $77 \mathrm{~K}$ using a Tristar II Plus (Micromeritics, Norcross, GA, USA) instrument after degassing for at least $3 \mathrm{~h}$ at $110^{\circ} \mathrm{C}$. The morphology of the nanoparticles was observed using transmission electron microscopy (TEM) in a Tecnai BioTWIN (Fei, Hillsboro, Oregon, USA) instrument operated with an acceleration voltage of $120 \mathrm{kV}$ and equipped with a $2 \mathrm{k} \times 2 \mathrm{k}$ Veleta OSiS CCD camera. For the TEM imaging, the nanoparticles were suspended in ethanol in a water-cooled cup horn system (VCX750, cup horn Part no. 630-0431, Sonics Vibracell, Newport, CT, USA) (10 min, 100\% amplitude) and one drop of the suspension was deposited onto a carbon coated copper grid (400 mesh carbon film, S160-4, Agar Scientific, Essex, UK). The grid was dried at ambient temperature overnight. Size distribution and surface charge of $\mathrm{CaP}$ and $\mathrm{CaP}$-loaded nanoparticles were evaluated by dynamic light scattering (DLS) and $\zeta$-potential analysis, respectively, in a Malvern Panalytical Zetasizer Ultra instrument (Malvern, UK) at $100 \mu \mathrm{g} / \mathrm{mL}$ particle concentration. Fourier transform infrared spectroscopy (FTIR) was performed on as-synthesized $\mathrm{CaP}$ nanoparticles and freeze-dried CaP conjugates in an Cary 630 FTIR spectrometer (Agilent, Kista, Sweden) in a wavenumber range of 400-4000 $\mathrm{cm}^{-1}$ with a $2 \mathrm{~cm}^{-1}$ resolution. Freeze-drying was performed in a Savant SpeedVac Plus SC210A lyophilizer (Thermo Scientific, Göteborg, Sweden) equipped with a refrigerated vapor trap (RVT4101, Thermo Scientific, Göteborg, Sweden). Absorbance measurements at $225 \mathrm{~nm}$ were performed using an Analytik Jena Specord 210 Plus ultraviolet and visible (UV-vis) spectrophotometer (Jena, Germany). The absorbance at $225 \mathrm{~nm}$ (where maximum absorbance of CaP nanoparticles was observed) is monitored over time in a partially covered cuvette in order to monitor only the top suspension layer according to the method presented in Spyrogianni et al. [49]. 


\subsection{Preparation of Nanoparticles Suspension and Macromolecules Adsorption}

Nanoparticle suspensions were prepared in phosphate buffer saline (PBS) at physiological pH 7.4 at an initial concentration of $1000 \mu \mathrm{g} / \mathrm{mL}$. More precisely, $5 \mathrm{mg}$ of the nanoparticles were dispersed in $5 \mathrm{~mL}$ of PBS pH 7.4 in a conical falcon polystyrene tube of $15 \mathrm{~mL}$, followed by vortex-mixing for $30 \mathrm{~s}$ and ultrasonication for $20 \mathrm{~min}$ in a water-cooled cup horn system (VCX750, cup horn Part no. 630-0431, Sonics Vibracell, Newport, CT, USA). Ultrasonic energy was provided in pulses (10s on, 2s off) at $60 \%$ amplitude. As the nanoparticles are prone to sedimentation, the ultrasonication was paused every $5 \mathrm{~min}$ and additional vortex-mixing was implemented for $10 \mathrm{~s}$ in order to optimize particle dispersion.

In order to establish the experimental protocol for loading biologics on CaP nanoparticles, bovine serum albumin (BSA, 296\%, Sigma-Aldrich, Stockholm, Sweden, MW: $66430.3 \mathrm{~g} / \mathrm{mol}$ ) and bradykinin acetate salt ( $\geq 98 \%$, Sigma-Aldrich, Stockholm, Sweden, MW: $1060.2 \mathrm{~g} / \mathrm{mol}$ ) were selected as model protein and peptide, respectively. BSA was selected as model protein because of its stability and its wide application in evaluating sustained drug release systems [55,56], whereas bradykinin is rather small and can act as model for the loading of larger ones. Further on, as a case study LL-37 antimicrobial peptide (LLGDFFRKSKEKIGKEFKRIVQRIKDFLRNLVPRTES, >95\%, Innovagen, Lund, Sweden, MW: $4493.3 \mathrm{~g} / \mathrm{mol}$ ) was loaded on CaP nanoparticles and the antibacterial efficiency of the LL-37-CaP nanoconjugates was evaluated.

Suspensions of protein and peptide-loaded CaP nanoparticles in PBS pH $7.4(200 \mu \mathrm{L}$ sample volume) were prepared by the addition of $100 \mu \mathrm{L}$ of dispersed CaP nanoparticles in PBS pH 7.4 to an equal volume of protein/peptide solution of initial concentration ranging from 200 to $2000 \mu \mathrm{g} / \mathrm{mL}$. The suspensions were placed on a roller mixer (Stuart SRT9D, Staffordshire, UK) for gentle mixing at $60 \mathrm{rpm}$ at room temperature for 1, 2, 4,6 and $24 \mathrm{~h}$ to investigate the effect of time on adsorption. The particles were separated via centrifugation at 10,000 rpm for 20 min (particle separation was confirmed by monitoring the luminescence of the CaP:Eu nanoparticles in the supernatant that was absent) and the supernatant containing the macromolecule content that has not been adsorbed was collected for quantification using a Pierce bicinchoninic acid (BCA) protein assay kit (ThermoFisher Scientific, Göteborg, Sweden) according to manufacturer's instructions. Absorbance was measured at $562 \mathrm{~nm}$ using a microplate reader (SpectraMax Plus, Molecular Devices, San Jose, CA, USA) and the amount of macromolecules was calculated from a calibration curve. The amount of protein/peptide was calculated from the difference between the initial concentration and the concentration of the supernatant. Furthermore, the loaded particles were washed once with PBS and re-dispersed in PBS. The amount of macromolecule after the washing was also quantified in the supernatant after centrifugation $(10,000 \mathrm{rpm}, 20 \mathrm{~min})$ and was found negligible $(\leq 5 \%)$ indicating the stability of the conjugates. The suspensions of the loaded particles were stored at $4{ }^{\circ} \mathrm{C}$ and used for further experiments within a week. The loading capacity of the nanoparticles was expressed as (mass of macromolecule adsorbed onto nanoparticles in $\mathrm{mg}$ )/(total mass of nanoparticles in $\mathrm{g}$ ). For each macromolecule concentration, at least three independent triplicates (from different particle suspensions and macromolecule solutions) were made and the final loading is presented as arithmetic mean \pm standard deviation of the independent sets of replicate measurements.

\subsection{Proteolysis and Growth Curves Analysis}

\subsubsection{Degradation Assay}

A total of $0.5 \mu \mathrm{g}$ LL-37, either loaded on nanoparticles or not, was subjected to Proteinase K degradation assay. Input samples were taken without Proteinase $\mathrm{K}$ added, as a positive control and is considered to be "100\%" when calculating protein amounts. LL-37 was incubated in $20 \mathrm{mM}$ Tris- $\mathrm{HCl}$, pH 8.0 with a total of $20 \mathrm{ng}$ Proteinase K (Qiagen, Hilden, Germany) added to the reaction. Samples were incubated at $37^{\circ} \mathrm{C}$ until given timepoints where the reaction was stopped by the addition of SDS loading buffer (at a final concentration of $50 \mathrm{mM}$ Tris- $\mathrm{HCl} \mathrm{pH} 6.8,2 \%$ SDS, 10\% glycerol, $1 \%$ 
$\beta$-mercaptoethanol, $12.5 \mathrm{mM}$ EDTA and $0.02 \%$ Bromophenol blue) and samples were then immediately boiled for $10 \mathrm{~min}$ at $98^{\circ} \mathrm{C}$.

\subsubsection{SDS-PAGE}

Samples were loaded onto a NuPAGE 4\%-12\% Bis-Tris gel (Invitrogen, Carlsbad, CA, USA) and run in MES-buffer (Invitrogen) at $40 \mathrm{~mA} /$ gel. Since LL-37 is a small peptide, samples were run only halfway through the gel. The gels where then washed in Mill-Q water 3 times, 10 min before immersion in Imperial Protein Stain (Thermo Scientific) for $1 \mathrm{~h}$. After that Mill-Q water was used to destain the gels before image acquisition on GelDoc XRS+ (Bio-Rad, Hercules, CA, USA). Bands were quantified using Image Studio Lite v. 5.2 (LI-COR Biosciences, Lincoln, NE, USA).

\subsubsection{Growth Curves}

The antimicrobial properties of LL-37-loaded $\mathrm{CaP}_{\mathrm{S}}$ nanoparticles were assessed against the Gram-negative E. coli (HVM52 strain) and Gram-positive S. pneumoniae serotype 4 strain TIGR4 (T4, ATCC BAA-334). E. coli was incubated under shaking at $200 \mathrm{rpm}$ overnight at $37^{\circ} \mathrm{C}$ in $2 \mathrm{~mL}$ of Luria Bertani (LB) medium. Pneumococcal strains were grown at $37^{\circ} \mathrm{C}$ on blood agar plates incubated overnight with $5 \% \mathrm{CO}_{2}$. Colonies were inoculated into $\mathrm{C}+\mathrm{Y}$ medium supplemented with $1 \% v / v$ of a mixture of heat inactivated horse serum and glucose to optical density at $600 \mathrm{~nm}\left(\mathrm{OD}_{600}\right) 0.1$, grown until exponential phase $\left(\mathrm{OD}_{600}=0.5\right)$, and again diluted to 0.05 with the aforementioned medium [52]. Bacterial growth was monitored in honeycomb multiwell plates using a Bioscreen $\mathrm{C}$ MBR instrument (Growth curves OY, Turku, Finland) in which the $\mathrm{OD}_{600}$ is recorded. Each sample was analyzed in triplicate. Imaging of bacterial cultures after $2 \mathrm{~h}$ incubation with the $\mathrm{CaP}_{\mathrm{S}}$-LL-37 at $37^{\circ} \mathrm{C}$ after staining with SYTO9 Green Fluorescent Nucleic Acid Stain (Invitrogen) was performed with a Delta Vision Elite microscope (Applied Precision, Uppsala, Sweden) under a 100× magnification objective. Z-stack projection images were acquired (excitation of the particles at $350 \mathrm{~nm}$ wavelength and emission at $570 \mathrm{~nm}$ wavelength and excitation of bacteria at $491 \mathrm{~nm}$ wavelength and emission at $516 \mathrm{~nm}$ wavelength). Images were acquired using SoftWoRx imaging program (Applied Precision, Uppsala, Sweden) and analyzed with ImageJ software.

\section{Conclusions}

We show here the engineering of CaP nanoparticles by FSP and evaluate their loading capacity as carriers of biological drugs (proteins and peptides). Different parameters affecting the loading capacity of CaP nanoparticles are investigated using BSA and bradykinin as model biomacromolecules (protein and peptide, respectively). More precisely, incubation time and macromolecule concentration are varied and that affects the amount of biological drug on the nanocarrier surface. High loading values are achieved due to the large surface-to-volume ratio of $\mathrm{CaP}$ nanoparticles and the fractal-like agglomerate structure of flame-made nanoparticles. The biological drug loading protocol is further implemented for the LL-37 antimicrobial peptide, a biological drug currently involved in various clinical trials. The amount of LL-37 that may be efficiently loaded on the flame-made CaP nanoparticles is the highest reported so far. Moreover, loading of LL-37 on CaP offers protection against enzymatic degradation, while the peptide functionality and antimicrobial activity against both Gram-positive and Gram-negative pathogens is retained upon loading. Therefore, the high drug loading of the developed nanocarriers here will facilitate the delivery of biologicals at diseased sites at high concentrations and therefore improve therapeutic efficiency.

Supplementary Materials: The following are available online. Table S1. Calculation of loading capacity from the literature, Table S2. LL-37 release at pH 7.4 after 2,6 and $24 \mathrm{~h}$ at $25^{\circ} \mathrm{C}$ and $37{ }^{\circ} \mathrm{C}$, Figure S1. Effect of concentration of BSA and bradykinin on the loading capacity of $\mathrm{CaP}_{\mathrm{L}}$ nanoparticles, Figure S2. Size distribution of $\mathrm{CaP}_{\mathrm{S}}$ nanoparticles (intensity \% data), Figure S3. Size distribution and $\zeta$-potential of $\mathrm{CaP}_{\mathrm{L}}$ nanoparticles, Figure S4. $\zeta$-potential of BSA, bradykinin and LL-37 vs pH, Figure S5. Absorbance values of LL-37-loaded CaP nanoparticles, Figure S6. Absorbance values at $600 \mathrm{~nm}$ of LL-37-loaded $\mathrm{CaP}_{\mathrm{S}}$ nanoparticles and of pure LL-37 in $\mathrm{LB}$ and $\mathrm{C}+\mathrm{Y}$ media, Figure S7. Effect of $\mathrm{CaP}_{\mathrm{S}}$ nanoparticle presence on bacterial growth. 
Author Contributions: Conceptualization, V.T. and G.A.S.; Data curation, V.T. and J.K.; Formal analysis, V.T., J.K., P.M., E.L., B.H.-N. and G.A.S.; Funding acquisition, E.L., B.H.-N. and G.A.S.; Methodology, V.T., J.K., P.M. and G.A.S.; Project administration, G.A.S.; Resources, E.L., B.H.-N. and G.A.S.; Supervision, G.A.S.; Visualization, V.T. and J.K.; Writing—original draft, V.T. and G.A.S.; Writing-review and editing, V.T., J.K., P.M., E.L., B.H.-N. and G.A.S. All authors have read and agreed to the published version of the manuscript.

Funding: This project has received funding from the European Research Council (ERC) under the European Union's Horizon 2020 research and innovation program (ERC Grant agreement $n^{\circ} 758705$ ). Funding from the Karolinska Institutet Board of Research, the Swedish Research Council (2016-03471; 2016-00228; 2016-01861; 2018-05798), the Jeansson Foundations (JS2016-0029), the Torsten Söderberg Foundation (M87/18), the Swedish Foundation for Strategic Research (SSF), Stockholm County Council, and the Knut and Alice Wallenberg Foundation is kindly acknowledged.

Acknowledgments: L. Lopez and J. Rodriguez are kindly acknowledged for providing E. coli (HVM52) bacterial stocks, and K. Vestö for discussions.

Conflicts of Interest: The authors declare no conflict of interest.

\section{References}

1. Biosimilars in the EU: Information Guide for Healthcare Professionals; European Medicines Agency: Amsterdam, The Netherlands, 2019.

2. Mullard, A. 2019 FDA drug approvals. Nat. Rev. Drug Discov. 2020, 19, 79-84. [CrossRef] [PubMed]

3. Anselmo, A.C.; Gokarn, Y.; Mitragotri, S. Non-invasive delivery strategies for biologics. Nat. Rev. Drug Discov. 2019, 18, 19-40. [CrossRef]

4. Soares, S.; Sousa, J.; Pais, A.; Vitorino, C. Nanomedicine: Principles, Properties, and Regulatory Issues. Front. Chem. 2018, 6, 360. [CrossRef] [PubMed]

5. Markwalter, C.E.; Pagels, R.F.; Hejazi, A.N.; Gordon, A.G.R.; Thompson, A.L.; Prud'homme, R.K. Polymeric Nanocarrier Formulations of Biologics Using Inverse Flash NanoPrecipitation. AAPS J. 2020, $22,18$. [CrossRef] [PubMed]

6. Kamaly, N.; Yameen, B.; Wu, J.; Farokhzad, O.C. Degradable Controlled-Release Polymers and Polymeric Nanoparticles: Mechanisms of Controlling Drug Release. Chem. Rev. 2016, 116, 2602-2663. [CrossRef]

7. Malmsten, M. Inorganic nanomaterials as delivery systems for proteins, peptides, DNA, and siRNA. Curr. Opin. Colloid Interface Sci. 2013, 18, 468-480. [CrossRef]

8. Liang, R.; Wei, M.; Evans, D.G.; Duan, X. Inorganic nanomaterials for bioimaging, targeted drug delivery and therapeutics. Chem. Commun. 2014, 50, 14071-14081. [CrossRef]

9. Bisso, S.; Mura, S.; Castagner, B.; Couvreur, P.; Leroux, J.-C. Dual delivery of nucleic acids and PEGylated-bisphosphonates via calcium phosphate nanoparticles. Eur. J. Pharm. Biopharm. 2019, 142, 142-152. [CrossRef]

10. Bhakta, G.; Mitra, S.; Maitra, A. DNA encapsulated magnesium and manganous phosphate nanoparticles: Potential non-viral vectors for gene delivery. Biomaterials 2005, 26, 2157-2163. [CrossRef]

11. Yu, J.; Hao, R.; Sheng, F.; Xu, L.; Li, G.; Hou, Y. Hollow manganese phosphate nanoparticles as smart multifunctional probes for cancer cell targeted magnetic resonance imaging and drug delivery. Nano Res. 2012, 5, 679-694. [CrossRef]

12. Zhuang, X.; Wu, T.; Zhao, Y.; Hu, X.; Bao, Y.; Guo, Y.; Song, Q.; Li, G.; Tan, S.; Zhang, Z. Lipid-enveloped zinc phosphate hybrid nanoparticles for codelivery of $\mathrm{H}-2 \mathrm{~Kb}$ and $\mathrm{H}-2 \mathrm{Db}$-restricted antigenic peptides and monophosphoryl lipid A to induce antitumor immunity against melanoma. J. Control. Release 2016, 228, 26-37. [CrossRef] [PubMed]

13. Chen, Y.; Deng, L.; Maeno-Hikichi, Y.; Lai, M.; Chang, S.; Chen, G.; Zhang, J. Formation of an Endophilin-Ca ${ }^{2+}$ Channel Complex Is Critical for Clathrin-Mediated Synaptic Vesicle Endocytosis. Cell 2003, 115, 37-48. [CrossRef]

14. Levingstone, T.J.; Herbaj, S.; Dunne, N.J. Calcium Phosphate Nanoparticles for Therapeutic Applications in Bone Regeneration. Nanomaterials 2019, 9, 1570. [CrossRef] [PubMed]

15. Zhang, Y.; Dong, R.; Park, Y.; Bohner, M.; Zhang, X.; Ting, K.; Soo, C.; Wu, B.M. Controlled release of NELL-1 protein from chitosan/hydroxyapatite-modified TCP particles. Int. J. Pharm. 2016, 511, 79-89. [CrossRef] 
16. Miragoli, M.; Ceriotti, P.; Iafisco, M.; Vacchiano, M.; Salvarani, N.; Alogna, A.; Carullo, P.; Ramirez-Rodríguez, G.B.; Patrício, T.; Esposti, L.D.; et al. Inhalation of peptide-loaded nanoparticles improves heart failure. Sci. Transl. Med. 2018, 10, eaan6205. [CrossRef]

17. Kojima, S.; Nagata, F.; Inagaki, M.; Kugimiya, S.; Kato, K. Avidin-adsorbed peptide-calcium phosphate composites exhibiting high biotin-binding activity. New J. Chem. 2019, 43, 427-435. [CrossRef]

18. Kojima, S.; Nagata, F.; Kugimiya, S.; Kato, K. Synthesis of peptide-containing calcium phosphate nanoparticles exhibiting highly selective adsorption of various proteins. Appl. Surf. Sci. 2018, 458, 438-445. [CrossRef]

19. Vanegas Sáenz, J.R.; Tenkumo, T.; Kamano, Y.; Egusa, H.; Sasaki, K. Amiloride-enhanced gene transfection of octa-arginine functionalized calcium phosphate nanoparticles. PLoS ONE 2017, 12, e0188347. [CrossRef]

20. Huang, X.; Andina, D.; Leroux, J.-C.; Castagner, B. Preparation of PEGylated chelator-stabilized calcium phosphate nanoparticles for liver-targeted delivery of nucleic acid. J. Control. Release 2015, 213, e116. [CrossRef]

21. Hua, S.; de Matos, M.B.C.; Metselaar, J.M.; Storm, G. Current Trends and Challenges in the Clinical Translation of Nanoparticulate Nanomedicines: Pathways for Translational Development and Commercialization. Front. Pharmacol. 2018, 9, 790. [CrossRef]

22. Wu, J.; Kamaly, N.; Shi, J.; Zhao, L.; Xiao, Z.; Hollett, G.; John, R.; Ray, S.; Xu, X.; Zhang, X.; et al. Development of Multinuclear Polymeric Nanoparticles as Robust Protein Nanocarriers. Angew. Chem. Int. Ed. 2014, 53, 8975-8979. [CrossRef] [PubMed]

23. Allen, S.; Osorio, O.; Liu, Y.-G.; Scott, E. Facile assembly and loading of theranostic polymersomes via multi-impingement flash nanoprecipitation. J. Control. Release 2017, 262, 91-103. [CrossRef] [PubMed]

24. Pratsinis, S.E. Aerosol-based technologies in nanoscale manufacturing: From functional materials to devices through core chemical engineering. AIChE J. 2010, 56, 3028-3035. [CrossRef]

25. Mohn, D.; Doebelin, N.; Tadier, S.; Bernabei, R.E.; Luechinger, N.A.; Stark, W.J.; Bohner, M. Reactivity of calcium phosphate nanoparticles prepared by flame spray synthesis as precursors for calcium phosphate cements. J. Mater. Chem. 2011, 21, 13963-13972. [CrossRef]

26. Parent, M.; Baradari, H.; Champion, E.; Damia, C.; Viana-Trecant, M. Design of calcium phosphate ceramics for drug delivery applications in bone diseases: A review of the parameters affecting the loading and release of the therapeutic substance. J. Control. Release 2017, 252, 1-17. [CrossRef] [PubMed]

27. Tonigold, M.; Simon, J.; Estupiñán, D.; Kokkinopoulou, M.; Reinholz, J.; Kintzel, U.; Kaltbeitzel, A.; Renz, P.; Domogalla, M.P.; Steinbrink, K.; et al. Pre-adsorption of antibodies enables targeting of nanocarriers despite a biomolecular corona. Nat. Nanotechnol. 2018, 13, 862-869. [CrossRef]

28. Mishra, D.K.; Shandilya, R.; Mishra, P.K. Lipid based nanocarriers: A translational perspective. Nanomedicine 2018, 14, 2023-2050. [CrossRef]

29. Kuroda, K.; Okumura, K.; Isogai, H.; Isogai, E. The Human Cathelicidin Antimicrobial Peptide LL-37 and Mimics are Potential Anticancer Drugs. Front. Oncol. 2015, 5, 144. [CrossRef]

30. Chen, C.H.; Lu, T.K. Development and Challenges of Antimicrobial Peptides for Therapeutic Applications. Antibiotics 2020, 9, 24. [CrossRef]

31. Braun, K.; Pochert, A.; Lindén, M.; Davoudi, M.; Schmidtchen, A.; Nordström, R.; Malmsten, M. Membrane interactions of mesoporous silica nanoparticles as carriers of antimicrobial peptides. J. Colloid Interface Sci. 2016, 475, 161-170. [CrossRef]

32. Fumakia, M.; Ho, E.A. Nanoparticles Encapsulated with LL37 and Serpin A1 Promotes Wound Healing and Synergistically Enhances Antibacterial Activity. Mol. Pharm. 2016, 13, 2318-2331. [CrossRef] [PubMed]

33. Comune, M.; Rai, A.; Chereddy, K.K.; Pinto, S.; Aday, S.; Ferreira, A.F.; Zonari, A.; Blersch, J.; Cunha, R.; Rodrigues, R.; et al. Antimicrobial peptide-gold nanoscale therapeutic formulation with high skin regenerative potential. J. Control. Release 2017, 262, 58-71. [CrossRef] [PubMed]

34. Martin-Serrano, Á.; Gómez, R.; Ortega, P.; de la Mata, F.J. Nanosystems as Vehicles for the Delivery of Antimicrobial Peptides (AMPs). Pharmaceutics 2019, 11, 448. [CrossRef] [PubMed]

35. Vignoni, M.; de Alwis Weerasekera, H.; Simpson, M.J.; Phopase, J.; Mah, T.-F.; Griffith, M.; Alarcon, E.I.; Scaiano, J.C. LL37 peptide@silver nanoparticles: Combining the best of the two worlds for skin infection control. Nanoscale 2014, 6, 5725-5728. [CrossRef] [PubMed]

36. Garcia-Orue, I.; Gainza, G.; Girbau, C.; Alonso, R.; Aguirre, J.J.; Pedraz, J.L.; Igartua, M.; Hernandez, R.M. LL37 loaded nanostructured lipid carriers (NLC): A new strategy for the topical treatment of chronic wounds. Eur. J. Pharm. Biopharm. 2016, 108, 310-316. [CrossRef] 
37. Chereddy, K.K.; Her, C.-H.; Comune, M.; Moia, C.; Lopes, A.; Porporato, P.E.; Vanacker, J.; Lam, M.C.; Steinstraesser, L.; Sonveaux, P.; et al. PLGA nanoparticles loaded with host defense peptide LL37 promote wound healing. J. Control. Release 2014, 194, 138-147. [CrossRef]

38. Hanifi, A.; Fathi, M.H.; Mir Mohammad Sadeghi, H. Effect of strontium ions substitution on gene delivery related properties of calcium phosphate nanoparticles. J. Mater. Sci. Mater. Med. 2010, 21, 2601-2609. [CrossRef]

39. Mädler, L.; Kammler, H.K.; Mueller, R.; Pratsinis, S.E. Controlled synthesis of nanostructured particles by flame spray pyrolysis. J. Aerosol Sci. 2002, 33, 369-389. [CrossRef]

40. Ataol, S.; Tezcaner, A.; Duygulu, O.; Keskin, D.; Machin, N.E. Synthesis and characterization of nanosized calcium phosphates by flame spray pyrolysis, and their effect on osteogenic differentiation of stem cells. J. Nanopart. Res. 2015, 17, 95. [CrossRef]

41. Loher, S.; Stark, W.J.; Maciejewski, M.; Baiker, A.; Pratsinis, S.E.; Reichardt, D.; Maspero, F.; Krumeich, F.; Günther, D. Fluoro-apatite and Calcium Phosphate Nanoparticles by Flame Synthesis. Chem. Mater. 2005, 17, 36-42. [CrossRef]

42. Swain, S.K.; Sarkar, D. Study of BSA protein adsorption/release on hydroxyapatite nanoparticles. Appl. Surf. Sci. 2013, 286, 99-103. [CrossRef]

43. Starsich, F.H.L.; Herrmann, I.K.; Pratsinis, S.E. Nanoparticles for Biomedicine: Coagulation during Synthesis and Applications. Annu. Rev. Chem. Biomol. Eng. 2019, 10, 155-174. [CrossRef] [PubMed]

44. Mavropoulos, E.; Costa, A.M.; Costa, L.T.; Achete, C.A.; Mello, A.; Granjeiro, J.M.; Rossi, A.M. Adsorption and bioactivity studies of albumin onto hydroxyapatite surface. Colloids Surf. B 2011, 83, 1-9. [CrossRef] [PubMed]

45. Wang, S.; Yan, C.; Zhang, X.; Shi, D.; Chi, L.; Luo, G.; Deng, J. Antimicrobial peptide modification enhances the gene delivery and bactericidal efficiency of gold nanoparticles for accelerating diabetic wound healing. Biomater. Sci. 2018, 6, 2757-2772. [CrossRef] [PubMed]

46. Liu, J.; Zong, G.; He, L.; Zhang, Y.; Liu, C.; Wang, L. Effects of Fumed and Mesoporous Silica Nanoparticles on the Properties of Sylgard 184 Polydimethylsiloxane. Micromachines 2015, 6, 855-864. [CrossRef]

47. Ozhukil Kollath, V.; Mullens, S.; Luyten, J.; Traina, K.; Cloots, R. Protein-calcium phosphate nanocomposites: Benchmarking protein loading via physical and chemical modifications against co-precipitation. RSC Adv. 2015, 5, 55625-55632. [CrossRef]

48. Alhazmi, H. FT-IR Spectroscopy for the Identification of Binding Sites and Measurements of the Binding Interactions of Important Metal Ions with Bovine Serum Albumin. Sci. Pharm. 2019, 87, 5. [CrossRef]

49. Spyrogianni, A.; Herrmann, I.K.; Lucas, M.S.; Leroux, J.-C.; Sotiriou, G.A. Quantitative analysis of the deposited nanoparticle dose on cell cultures by optical absorption spectroscopy. Nanomedicine 2016, 11, 2483-2496. [CrossRef]

50. Oren, Z.; Lerman, J.C.; Gudmundsson, G.H.; Agerberth, B.; Shai, Y. Structure and organization of the human antimicrobial peptide LL-37 in phospholipid membranes: Relevance to the molecular basis for its non-cell-selective activity. Biochem. J. 1999, 341, 501. [CrossRef]

51. Stevenson, K.; McVey, A.F.; Clark, I.B.N.; Swain, P.S.; Pilizota, T. General calibration of microbial growth in microplate readers. Sci. Rep. 2016, 6, 38828. [CrossRef]

52. Mellroth, P.; Daniels, R.; Eberhardt, A.; Rönnlund, D.; Blom, H.; Widengren, J.; Normark, S.; Henriques-Normark, B. LytA, Major Autolysin of Streptococcus pneumoniae, Requires Access to Nascent Peptidoglycan. J. Biol. Chem. 2012, 287, 11018-11029. [CrossRef] [PubMed]

53. Leszczynska, K.; Namiot, D.; Byfield, F.J.; Cruz, K.; Zendzian-Piotrowska, M.; Fein, D.E.; Savage, P.B.; Diamond, S.; McCulloch, C.A.; Janmey, P.A.; et al. Antibacterial activity of the human host defence peptide LL-37 and selected synthetic cationic lipids against bacteria associated with oral and upper respiratory tract infections. J. Antimicrob. Chemother. 2013, 68, 610-618. [CrossRef] [PubMed]

54. Wnorowska, U.; Niemirowicz, K.; Myint, M.; Diamond, S.L.; Wróblewska, M.; Savage, P.B.; Janmey, P.A.; Bucki, R. Bactericidal Activities of Cathelicidin LL-37 and Select Cationic Lipids against the Hypervirulent Pseudomonas aeruginosa Strain LESB58. Antimicrob. Agents Chemother. 2015, 59, 3808-3815. [CrossRef] [PubMed] 
55. Song, F.; Li, Y.; Wang, S.; Zhang, L.; Chen, Q. Multifunctional dual-mesoporous silica nanoparticles loaded with a protein and dual antitumor drugs as a targeted delivery system. New J. Chem. 2019, 43, 17284-17297. [CrossRef]

56. Ching Lau, C.; Reardon, P.J.T.; Campbell Knowles, J.; Tang, J. Phase-Tunable Calcium Phosphate Biomaterials Synthesis and Application in Protein Delivery. ACS Biomater. Sci. Eng. 2015, 1, 947-954. [CrossRef]

Sample Availability: Samples of the CaPS and CaPL compounds are available from the authors.

(C) 2020 by the authors. Licensee MDPI, Basel, Switzerland. This article is an open access article distributed under the terms and conditions of the Creative Commons Attribution (CC BY) license (http://creativecommons.org/licenses/by/4.0/). 